\title{
The effect of immunosuppression on the development of cerebral oedema in an experimental model of intracerebral haemorrhage: whole body and regional irradiation
}

\author{
P J Kane, P Modha, R D Strachan, S Cook, I R Chambers, C B Clayton,
} A D Mendelow

\begin{abstract}
The oedema which forms around an intracerebral haemorrhage has a complex aetiology. The immune response may have a role in its formation. There is clinical and experimental evidence that circulating leucocytes and platelets may mediate oedema formation. Global depletion of circulating leucocytes and platelets by whole body irradiation in a rodent model of intracerebral haemorrhage was found to confer protection against both ischaemia and oedema formation. This was not a direct effect of irradiation of the brain. The possible mechanisms for this protection are discussed.
\end{abstract}

$(\Im$ Neurol Neurosurg Psychiatry 1992;55:781-786)

Spontaneous intracerebral haemorrhage is a significant cause of mortality and morbidity. ${ }^{1}$ Brain oedema secondary to the haemorrhage is a major clinical problem which often proves refractory to treatment. In experimental models the brain oedema that develops after intracerebral haemorrhage is, in part, due to

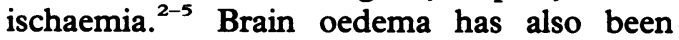
shown to follow the inflation of a $50 \mu \mathrm{l}$ balloon in a model which simulates the mechanical component of a rapidly expanding mass in the rat caudate nucleus. ${ }^{6}$

Attention has recently focused on the role of the cellular constituents of blood in generating cerebral oedema. This can be considered from two points of view: firstly, the direct effect of the cellular constituents within the haematoma, and secondly, the influence of circulating red cells, leucocytes, and platelets on the development of ischaemic oedema. With the first consideration in mind, Jenkins et al have shown that stereotactic injection of autologous blood into the basal ganglia of rats produces greater ischaemia than an equal volume of inert oil of cerebrospinal fluid. ${ }^{2}$ Suzuki and Ebina, in a similar experiment on dogs, have shown that the volume of oedematous brain is greater after injection of blood than after injection of an inert oil. ${ }^{7}$ Both ischaemia and oedema are therefore not merely a result of the mass effect of the haematoma but are dependent on other factors inherent within the blood inside the haematoma.

With regard to the second mechanism, neutrophils and platelets have been shown to accumulate rapidly in ischaemic brain both experimentally $^{89}$ and in human stroke. ${ }^{10} \mathrm{Cir}-$ culating neutrophils have a role in producing ischaemic damage in heart, ${ }^{11}$ bowel, ${ }^{12}$ and lung ${ }^{13}$ and have been implicated in the generation of ischaemic brain damage. ${ }^{14-17}$ Similarly, platelets have the potential to cause ischaemic brain damage. ${ }^{18}$ The aim of this study was to determine whether depletion of circulating leucocytes and platelets influences the production of cerebral oedema in a rat model of intracerebral haemorrhage.

\section{Methods}

Adult male Wistar rats (280-370 g) were used for the study. All experiments were performed in accordance with the Animals (Scientific Procedures) Act 1986.

Intracerebral haemorrhage was simulated by inflation of a microballoon placed stereotaxically in the right caudate nucleus, as previously described by Kingman et al. ${ }^{19}$ This model has been extensively investigated and proved to produce brain oedema. ${ }^{\circ}$

Leucocyte and platelet depletion were achieved by bone marrow suppression using sublethal irradiation with $x$ rays. ${ }^{20}$ The specification of $x$ ray quality was $240 \mathrm{kV}$ constant potential and $3.3 \mathrm{~mm} \mathrm{Cu}$ half value thickness. The rat, including tail, was restrained in a perspex tube. The tube design prevented the rat from moving during the period of irradiation without compromising ventilation and without the need for anaesthesia. An $x$ ray dose of $5 \mathrm{~Gy}$ was given over 15 minutes, either as a whole body dose or, by appropriate lead shielding, to the head alone or the body and tail alone. Uniformity of dose distribution throughout the irradiated volume within a range of $5 \%$ was achieved by treating the immobilised animal equally through each flank. Control animals were restrained in the tube for an equivalent period but were not irradiated. Experiments were performed in three groups.

Group 1: Whole body irradiation, 4 hour oedema measurement

Surgery took place four days after whole body irradiation (treated $n=7$, control $n=5$ ). Anaesthesia was induced in an atmosphere of $3-5 \%$ halothane in nitrous oxide-oxygen (70\%: $30 \%$ ) and maintained by face mask (halothane reduced to $1-2 \%$ ) while a tra- 
cheostomy was performed and mechanical ventilation initiated. Thereafter anaesthesia was maintained using $0.5-1 \%$ halothane. Expiratory carbon dioxide was continuously monitored by using a capnograph and recorded on a polygraph. Body temperature was maintained at $37^{\circ} \mathrm{C}$ by using a homoeothermic heating unit. The left femoral artery was cannulated to allow serial measurement of blood gas tensions, glucose concentration, packed cell volume, and pre lesion full blood count and differential white cell count. Pulsatile and mean arterial blood pressure were continuously monitored and recorded on a polygraph. The left femoral vein was cannulated to allow fluid replacement at $2-3 \mathrm{ml}$ per hour. The rat was then placed in a stereotaxic frame and a midline sagittal scalp incision made. After reflecting the pericranium burr holes were made to allow insertion of the microballoon (right side, $2.8 \mathrm{~mm}$ lateral and $1.1 \mathrm{~mm}$ anterior to the bregma) and bilateral frontal and parietal platinum cortical electrodes $(2.8 \mathrm{~mm}$ lateral and $3 \mathrm{~mm}$ anterior/posterior to the bregma) for cerebral blood flow measurements using a hydrogen clearance technique. $^{2122}$ The electrode diameter was $125 \mu \mathrm{m}$ and the electrodes were placed to a depth of $1 \mathrm{~mm}$ into the cortex. The position of the right sided electrodes was designed such that they would lie in the ischaemic penumbra of the simulated intracerebral haemorrhage. ${ }^{23}$ Baseline cerebral blood flow measurements were taken at this point. A microballoon (Ingenor Laboratories) mounted on the tip of a blunted $25 \mathrm{~g}$ butterfly needle was inflated to $50 \mu \mathrm{l}$ with saline to test its integrity. It was then deflated and inserted to a depth of $5.5 \mathrm{~mm}$ into the right caudate nucleus and then re inflated to $50 \mu \mathrm{l}$ with saline. It remained inflated for the duration of the experiment. Cerebral blood flow measurements were taken at five and 30 minutes after inflation and thereafter every 30 minutes. At 240 minutes the animal was killed with intravenous pentobarbitone and the brain rapidly removed for oedema measurements.

Group 2: Whole body irradiation, 72 hour oedema measurement

Surgery took place four days after whole body irradiation (treated $n=8$, control $n=7$ ). Before surgery venesection for full blood count and differential white cell count was performed. Anaesthesia was induced by intraperitoneal injection of a mixture of midazolam $(1.25 \mathrm{mg} / \mathrm{ml})$, fentanyl $(0.08 \mu \mathrm{g} / \mathrm{ml})$, and fluanisone $(0.25 \mathrm{mg} / \mathrm{ml})$ at a dose of $1 \mathrm{ml} / 300 \mathrm{~g}$ body weight. This method of anaesthesia maintains normal blood pressure and arterial blood gas tensions in spontaneously breathing rats. ${ }^{2425}$

A microballoon was inserted as for group 1. It was inflated to $50 \mu$ l with saline for five minutes, deflated, and removed. In a previous study this period of balloon inflation followed by reperfusion of the adjacent brain produced significant oedema. After ensuring haemostasis the burr hole was sealed with bone wax, sprayed with topical antibiotic, and the wound sutured. The rat was transferred to an oxy- genated incubator for recovery. In the early postoperative period it received buprenorphine analgesia $^{26}$ and $5 \mathrm{ml}$ of dextrose/saline subcutaneously as fluid replacement because rats frequently take no oral fluids in the 24 hours postoperatively. At $\mathbf{7 2}$ hours the rat was anaesthetised in an atmosphere of $5 \%$ halothane and killed with an intracardiac injection of pentobarbitone; the brain was rapidly removed for oedema measurements.

Group 3: Differential irradiation, 72 hour oedema measurement

Surgery took place seven days after irradiation. This increase in time between irradiation and surgery leads to greater depletion of leucocytes and platelets at the time of balloon inflation. Treatment groups were: whole body irradiation $(n=10)$; head only irradiation $(n=10)$; body only irradiation $(n=9)$; control $(n=24)$. The animals were treated as for group 2.

\section{Assessment of brain oedema}

Coronal slices of both hemispheres, $1 \mathrm{~mm}$ thick, were taken either side of the point of entry of the microballoon on the right cortical surface. Two 1-2 $\mathrm{mm}^{3}$ samples of tissue were taken from the cortex overlying the haematoma, from the white matter adjacent to the haematoma, and from the caudate nucleus in the penumbra of the haematoma. Equivalent samples were taken from the left hemisphere and also paired control samples from both cerebellar hemispheres. Brain oedema measurements were made using the gravimetric technique described by Nelson et $a l^{27}$ but modified according to Shigeno et al. ${ }^{28}$

The samples were dropped into the gravimetric column and their level of descent measured after one minute. The specific gravity of the sample was calculated using a linear regression analysis derived from calibration of the column with droplets of potassium sulphate of known specific gravity. All columns had a correlation coefficient greater than 0.999 .

The investigators remained blind to the treatment groups until all experiments were completed. Statistical analysis of the group 1 and group 2 experiments was carried out using an unpaired Students $t$ test. Analysis of the group 3 results was performed using a one way analysis of variance (ANOVA). When this analysis confirmed the presence of significant differences between the treatment groups, these were further evaluated with an unpaired Students $t$ test using the pooled variance derived from the ANOVA. ${ }^{29}$

\section{Results}

Group 1: Whole body irradiation, 4 hour oedema measurement

PHYSIOLOGICAL VARIABLES

There were no significant differences detected in $\mathrm{pH}$, the carbon dioxide and oxygen pressures, and mean arterial blood pressure between control and irradiated animals (table 1). 
Table 1 Mean (SE) physiological variables in group 1

\begin{tabular}{|c|c|c|c|c|c|c|c|c|}
\hline \multirow[b]{2}{*}{ Time (minutes) } & \multicolumn{2}{|l|}{$p H$} & \multicolumn{2}{|c|}{$\mathrm{PCO}_{2}(\mathrm{~mm} \mathrm{Hg})$} & \multicolumn{2}{|c|}{$\mathrm{PO}_{2}(\mathrm{~mm} \mathrm{Hg})$} & \multicolumn{2}{|c|}{$M A B P(m m H g)$} \\
\hline & Control & Irradiated & Control & Irradiated & Control & Irradiated & Control & Irradiated \\
\hline $\begin{array}{l}\text { Baseline } \\
5 \\
30 \\
60 \\
90 \\
120 \\
150 \\
180 \\
210 \\
240\end{array}$ & $\begin{array}{l}7.42(0.03) \\
7.47(0.03) \\
7.42(0.03) \\
7.43(0.01) \\
7.43(0.01) \\
7.43(0.02) \\
7.43(0.01) \\
7.44(0.02) \\
7.39(0.03) \\
7.41(0.01)\end{array}$ & $\begin{array}{l}7.47(0.01) \\
7.46(0.01) \\
7.45(0.01) \\
7.43(0.01) \\
7.43(0.01) \\
7.41(0.02) \\
7.47(0.03) \\
7.45(0.01) \\
7.43(0.01) \\
7.43(0.01)\end{array}$ & $\begin{array}{l}37(2) \\
33(2) \\
34(2) \\
34(1) \\
34(1) \\
35(1) \\
36(1) \\
37(1) \\
37(1) \\
37(2)\end{array}$ & $\begin{array}{l}36(1) \\
36(1) \\
36(1) \\
35(1) \\
34(1) \\
35(1) \\
36(1) \\
34(1) \\
35(1) \\
36(1)\end{array}$ & $\begin{array}{l}180(15) \\
204(11) \\
178(6) \\
179(4) \\
183(8) \\
181(9) \\
179(8) \\
177(4) \\
182(5) \\
183(7)\end{array}$ & $\begin{array}{l}192(15) \\
181(11) \\
186(16) \\
172(15) \\
181(12) \\
169(10) \\
158(13) \\
178(4) \\
173(9) \\
176(4)\end{array}$ & $\begin{array}{l}116(4) \\
126(6) \\
130(6) \\
121(9) \\
126(7) \\
116(14) \\
119(5) \\
111(6) \\
115(5) \\
112(7)\end{array}$ & $\begin{array}{l}116(4) \\
121(5) \\
120(3) \\
117(7) \\
114(5) \\
115(7) \\
110(5) \\
109(5) \\
113(4) \\
109(5)\end{array}$ \\
\hline
\end{tabular}

$\mathrm{PCO}_{2}=$ arterial carbon dioxide tension.

$\mathrm{Po}_{2}=$ arterial oxygen tension.

$\mathrm{MA} B \mathrm{P}=$ Mean arterial blood pressure.

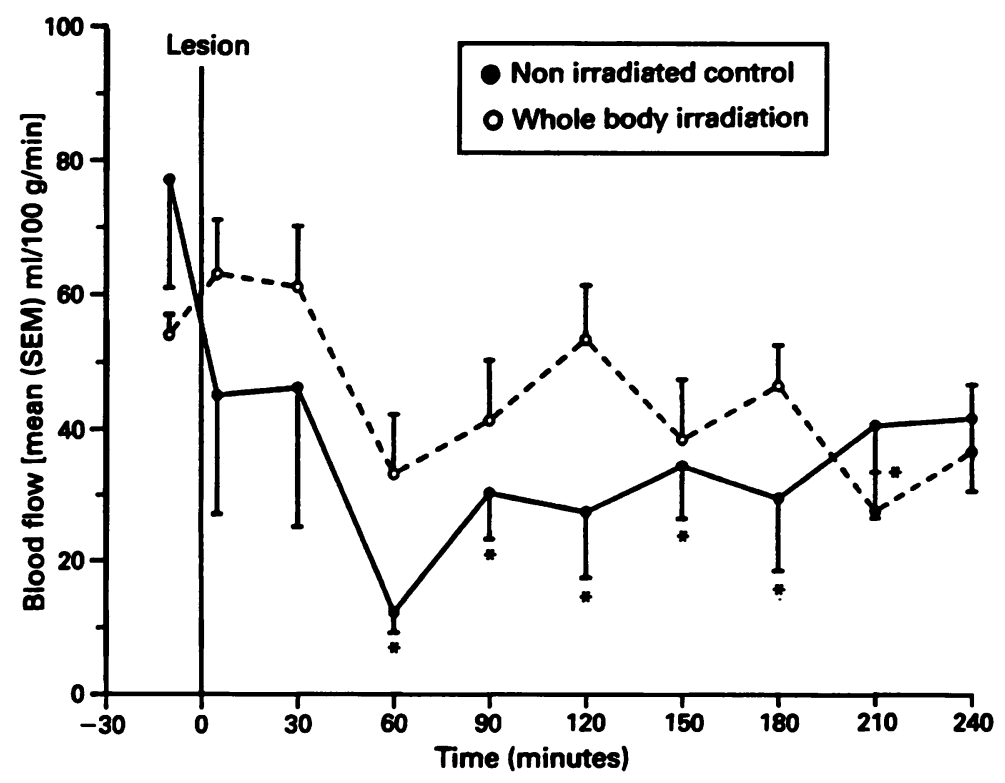

Figure 1 Right frontal cortical blood flow in whole body irradiated rats and non-irradiated controls (group 1). ${ }^{*} p<0.05$ compared with baseline value (Student's $t$ test).

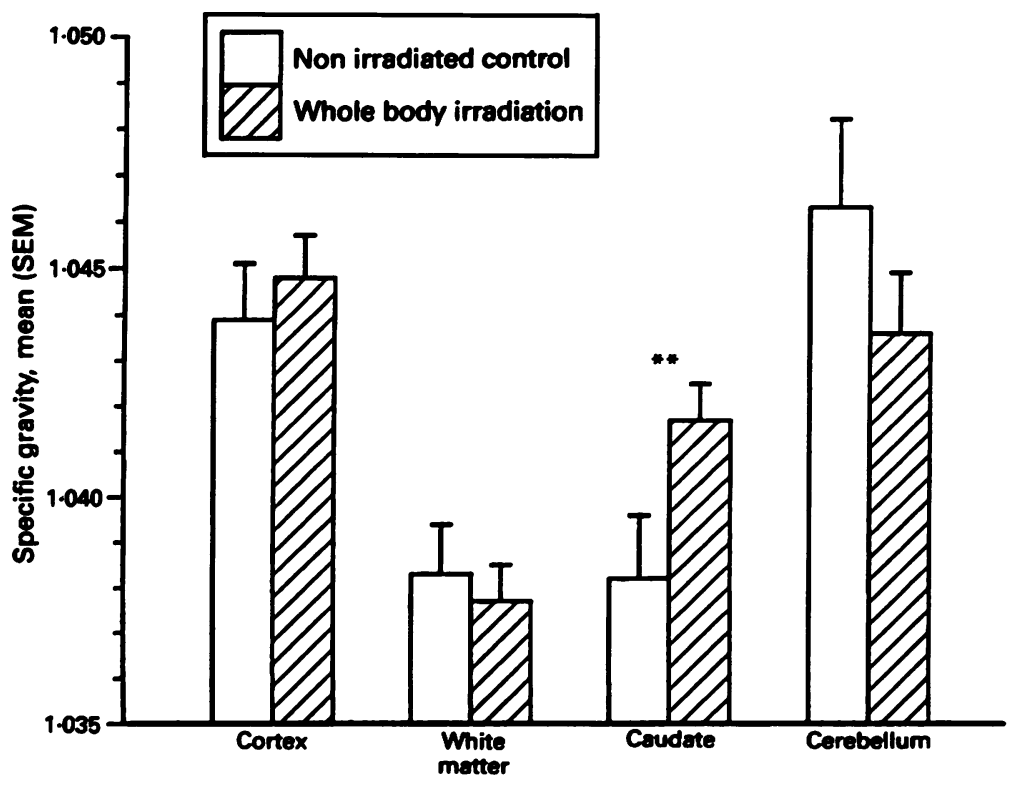

Figure 2 Oedema measurement in right hemisphere four hours after lesion in whole body irradiated rats and non-irradiated controls (group 1). ${ }^{\star *} p<0.01$ between groups (Student's $t$ test).
Table 2 Mean (SE) leucocyte and platelet counts $\left(\times 10^{\circ} / l\right)$ in groups 1 and 2

\begin{tabular}{|c|c|c|}
\hline & $\begin{array}{l}\text { Leucocyte count } \\
(\text { mean } \pm S E M \times\end{array}$ & $\begin{array}{l}\text { Platelet count } \\
\left.10^{9} / \mathrm{l}\right)\left(\text { mean } \pm S E M \times 10^{9} / \mathrm{l}\right)\end{array}$ \\
\hline $\begin{array}{l}\text { Group 1 (4 } \\
\text { Control } \\
\text { Irradiated }\end{array}$ & $\begin{array}{l}\text { h): } \\
5.8(0.82) \\
0.96(0.12)^{\star}\end{array}$ & $\begin{array}{l}609(79) \\
304(22)^{\star}\end{array}$ \\
\hline $\begin{array}{l}\text { Group } 2 \text { (72 } \\
\text { Control } \\
\text { Irradiated }\end{array}$ & $\begin{array}{l}\text { h) } \\
7.5(0.87) \\
1.7(0.33)^{\star}\end{array}$ & $\begin{array}{l}641(47) \\
366(70)^{\star}\end{array}$ \\
\hline
\end{tabular}

$\star=\mathrm{p}<0.01$ (Student's $t$ test).

HAEMATOLOGICAL INDICES

Platelet and white blood cell count were significantly reduced in the irradiated animals when compared with the control group (table 2).

CEREBRAL BLOOD FLOW

In the non-irradiated control animals there was a significant reduction in blood flow in the right frontal region at $60,90,120,150$, and 180 minutes when compared with baseline values (fig 1 ). In the irradiated group a significant reduction in flow was observed only at 210 minutes (fig 1). Right parietal blood flow was significantly reduced at 210 minutes in the control group but not in the irradiated group. No significant blood flow changes were found in the left (unoperated) hemisphere in either group.

BRAIN OEDEMA MEASUREMENT

All animals developed significant oedema in the right hemisphere in tissues around the simulated intracerebral haemorrhage. There was significantly less oedema formation in the right caudate nucleus of irradiated animals when compared with controls (fig 2). No significant changes were detected in the other areas investigated.

Group 2: Whole body irradiation, 72 hour oedema measurement

HAEMATOLOGICAL INDICES

Platelet and white blood cell count were significantly reduced in the irradiated animals when compared with the control group (table 2).

BRAIN OEDEMA MEASUREMENT

All animals developed significant oedema in the right hemisphere in tissues around the 
simulated intracerebral haemorrhage. There was significantly less oedema formation in the right caudate nucleus of the irradiated animals when compared with non-irradiated controls (fig 3). No significant changes were detected in other areas investigated, though there was a trend towards less oedema formation in the cortex and white matter in the irradiated group.

Group 3: Differential irradiation, 72 hour oedema measurement

HAEMATOLOGICAL INDICES

Changes in the leucocyte, platelet, and differ-

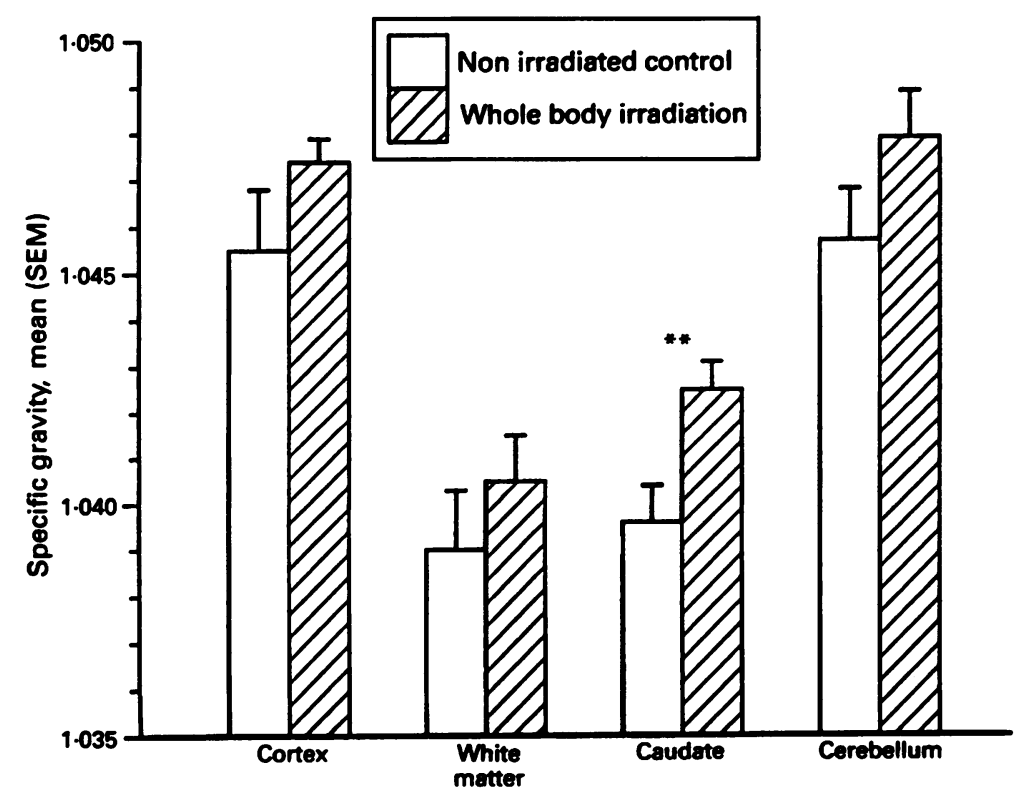

Figure 3 Oedema measurement in right hemisphere 72 hours after lesion in whole body irradiated rats and non-irradiated controls (group 1 ). ${ }^{\star \star}{ }_{p}<0.01$ between groups (Student's $t$ test).

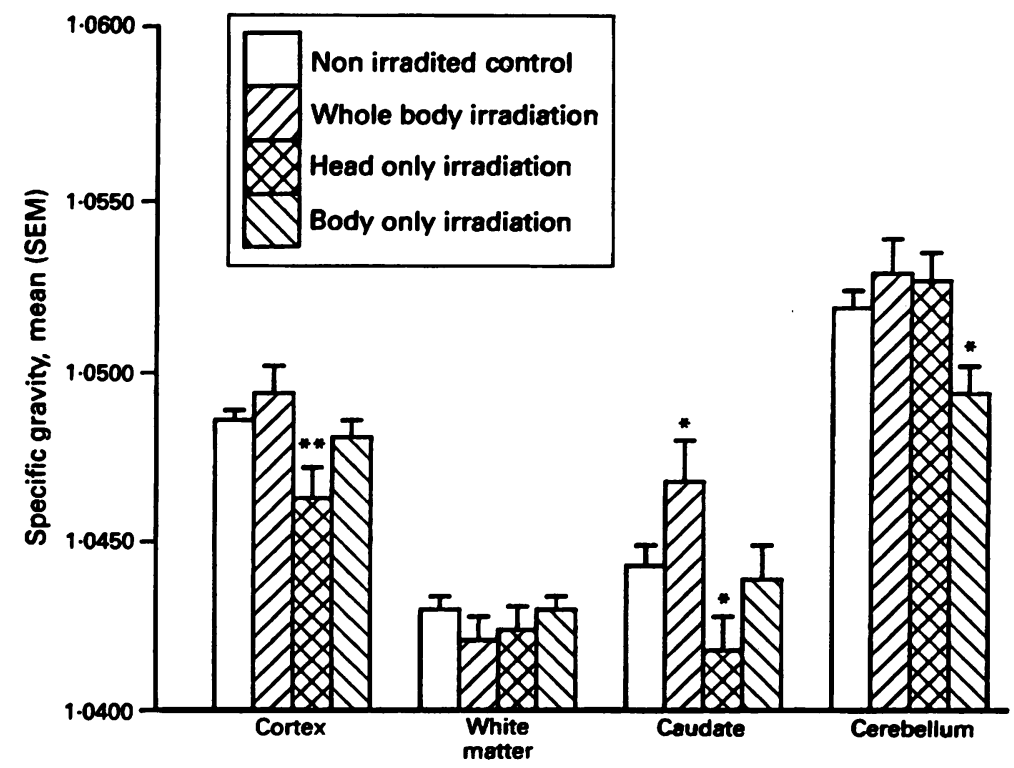

Figure 4 Oedema measurement in right hemisphere 72 hours after lesion in rats receiving irradiation to the whole body, head only, or body only compared with non-irradiated controls (group 1). ${ }^{*} p<0.05,{ }^{*} *_{p}<0.01$ compared with control (one way $A N O V A$ ). ential white cell counts with time in each of the treatment groups are shown in table 3. The animals treated with whole body or body only irradiation showed a significant reduction in the circulating leucocyte and platelet counts when compared with the controls. In both groups the neutrophil and lymphocyte counts were both reduced, with the lymphocytes showing a greater percentage change from pretreatment values. The reduction in leucocyte and platelet counts was quantitatively greater with whole body irradiation than with body only irradiation, although this did not achieve significance. The trend to higher values for each cell type in the body only irradiated group presumably reflects the haemopoietic activity of the skull marrow. In the head only irradiated group the leucocyte count was significantly increased when compared with control values whereas platelet count was not significantly different. This increase in leucocyte count was made up wholly by an increase in circulating neutrophils.

BRAIN OEDEMA MEASUREMENT (fig 4)

All animals developed significant oedema in the right hemisphere in tissues around the simulated intracerebral haemorrhage. Head only irradiation produced significantly greater oedema in both cortex and caudate nucleus when compared with control values. Whole body irradiation resulted in significantly less oedema in the caudate. Although a trend in this direction was also observed in the cortex, this was not significant. Body only irradiation did not confer any protective or detrimental effect in cortex, caudate, or white matter. Cerebellar specific gravity was significantly lower in this group. This might be explained by the difficulty in cutting the cerebellum to produce pure cortical samples for microgravimetry. Therefore whole body irradiation seems to confer some protection against the development of oedema that is independent of a local effect of the irradiation on the brain.

\section{Discussion}

The oedema that surrounds an intracerebral haemorrhage is a complex phenomenon. Its production is dependent on the interaction of a wide variety of local factors.

The mechanical disruption and compression of brain tissue by an expanding haematoma produces a penumbra of ischaemic and oedematous brain. ${ }^{26}$ Experiments in animal models have shown that the volume of oedema and ischaemia is greater when intracerebral haemorrhage is simulated by injection of blood into the basal ganglia than when an inert substance is injected. ${ }^{27}$ The implication is that cellular blood constituents themselves have an additional causal role in brain oedema. Our results lend support to these observations, in that global depletion of circulating leucocytes and platelets using whole body irradiation leads to less ischaemia and oedema in a rodent model of intracerebral haemorrhage. As the "haematoma" in this study is an inert mass the results suggest that the circulating leucocytes and 
Table 3 Mean (SE) white blood cell counts $\left(\times 10^{9} / \mathrm{l}\right)$ in group 3 (72 hour oedema measurement

\begin{tabular}{|c|c|c|c|}
\hline Cell type & Pretreatment & At time of lesion & $\begin{array}{l}\text { At time of brain oedema } \\
\text { measurement }\end{array}$ \\
\hline \multicolumn{4}{|c|}{ Control (non-irradiated) } \\
\hline $\begin{array}{l}\text { Leucocyte } \\
\text { Neutrophil } \\
\text { Lymphocyte } \\
\text { Platelet }\end{array}$ & $\begin{array}{l}9.46(0.97) \\
1 \cdot 11(0 \cdot 11) \\
8 \cdot 15(0.84) \\
882(39)\end{array}$ & $\begin{array}{c}9.02(0.55) \\
1.43(0.15) \\
7 \cdot 31(0.49) \\
771(31) \dagger\end{array}$ & $\begin{array}{c}6.54(0.37) \dagger \dagger \\
0.89(0.15) \\
5.4(0.27)+\dagger \\
1066(27)+{ }^{+}+\end{array}$ \\
\hline \multicolumn{4}{|c|}{ Whole body irradiated } \\
\hline $\begin{array}{l}\text { Leucocyte } \\
\text { Neutrophil } \\
\text { Lymphocyte } \\
\text { Platelet }\end{array}$ & $\begin{array}{l}7.24(0.51) \\
0.987(0 \cdot 13) \\
6.08(0.42) \\
943(69)\end{array}$ & $\begin{array}{l}2.26(0.36)^{\star \star}+\dagger \dagger \\
0.51(0 \cdot 1) \dagger \\
1.62(0.25)^{\star \star}+\dagger \dagger \\
199(22)+\dagger \dagger\end{array}$ & $\begin{array}{l}1.92(0.19)^{\star \star \star}+\dagger \dagger \\
0.864(0 \cdot 12) \\
0.89(0 \cdot 12)^{\star \star \star}+\dagger \dagger \\
18(2)^{\star \star \star \dagger \dagger}\end{array}$ \\
\hline \multicolumn{4}{|c|}{ Head only irradiated } \\
\hline $\begin{array}{l}\text { Leucocyte } \\
\text { Neutrophil } \\
\text { Lymphocyte } \\
\text { Platelet }\end{array}$ & $\begin{array}{l}12.95(1.9)^{\star} \\
1.88(0.53) \\
10.7(1.4) \\
824(22)\end{array}$ & $\begin{array}{l}14 \cdot 76(4 \cdot 1)^{\star} \\
3 \cdot 16(0 \cdot 81)^{\star \star \star} \\
10 \cdot 1(3 \cdot 2) \\
678(39) \dagger \dagger\end{array}$ & $\begin{array}{c}6.85(0.5) \dagger \\
0.865(0.13) \\
5.7(0.55) \dagger+ \\
871(42)^{\star \star \star}\end{array}$ \\
\hline \multicolumn{4}{|c|}{ Body only irradiated } \\
\hline $\begin{array}{l}\text { Leucocyte } \\
\text { Neutrophil } \\
\text { Lympyocyte } \\
\text { Platelet }\end{array}$ & $\begin{array}{l}8.03(0.57) \\
0.99(0.16) \\
6.07(0.69) \\
890(28)\end{array}$ & $\begin{array}{l}3.25(0.56)^{\star}+\dagger \dagger \\
0.70(0.16) \\
2 \cdot 17(0.4)^{\star \star}+\dagger \dagger \\
273(32)+\dagger \dagger\end{array}$ & $\begin{array}{l}1.82(0.14)^{\star \star \star}++\dagger \\
0.63(0.12) \\
1.2(0.09)^{\star \star \star}+\dagger \dagger \\
171(14)^{\star \star \star}+\dagger \dagger\end{array}$ \\
\hline
\end{tabular}

${ }^{\star} \mathrm{p}<0.05,{ }^{\star \star} \mathrm{p}<0.01,{ }^{\star \star \star} \mathrm{p}<0.001$. Statistical differences relative to control value (one way ANOVA).

$\dagger_{\mathrm{p}}<0.05, \dagger_{\mathrm{p}}<0.01,+\dagger \dagger_{\mathrm{p}}<0.001$. Statistical differences relative to pretreatment value $(t$ test). ficial effects in our model, ${ }^{35}$ and this observation has been supported by recent studies. ${ }^{36-38}$ In our study the lowest neutrophil counts were found in the whole body irradiated group and the highest counts in the head only irradiated group, which lends support to the hypothesis that the neutrophil has a role in oedema formation.

Lymphocytes have been shown to accumulate in ischaemic brain. ${ }^{39}$ No data are available on their role in producing cerebral oedema. Interestingly, when ischaemic brain damage has been reduced by leucocyte depletion, the circulating lymphocyte count is reduced by over half. ${ }^{14}{ }^{15}$ Similar large reductions in lymphocyte count were observed in the whole body and body only irradiated groups in this study. The immune system has been implicated in the production of vasospasm after subarachnoid haemorrhage ${ }^{40}$ and may be involved in the production of arterial spasm and ischaemia around an intracerebral haemorrhage. Cyclosporin, a potent immunosuppressant drug, has been shown to reduce vasospasm after experimental subarachnoid haemorrhage. ${ }^{41}$

Depletion of macrophages has been shown to be protective against ischaemic damage in a model of spinal injury. ${ }^{42}$ No data are available on their role in generating ischaemic damage in the brain.

Platelets accumulate in ischaemic brain. ${ }^{9}$ They are known to release a variety of vasoactive substances ${ }^{18434}$ which can produce vascular and neuronal damage. Platelet activating factor may play a central role in producing oedema ${ }^{45}$ by linking the leucocyte mediated component with the platelet mediated damage. In the whole body irradiated group profound thrombocytopenia had occurred by the time oedema was measured. This did not occur in the body only irradiated group. This may explain why the body only irradiation did not protect against oedema formation despite causing comparable degrees of leucopenia.

In conclusion, depletion of circulating leucocytes and platelets by whole body irradiation confers protection against ischaemia and oedema in an experimental model of intracerebral haemorrhage. This was independent of any local effect of the irradiation. Current evidence is inconclusive on the nature of the cell types that may be involved in oedema formation. The multiplicity of active metabolites that can be released at the site of haematoma by leucocytes and platelets suggests that they all probably have a role and that oedema formation is not the "privilege" of a single blood cell type. The activity of the individual blood cell subgroups after intracerebral haemorrhage deserves further study.

We thank Sarah Barwick and Janet Clark for preparing the manuscript. P J K was supported by the Harker Foundation supported by a Northern Regional Health Authority research fellowship. Part of this work was presented at Brain oedema 1990, Bern, Switzerland, June 1990. implicated in the production of ischaemic damage in several organs. ${ }^{11-13}$ Some evidence exists that they contribute to ischaemic brain damage. ${ }^{14-17}$ However, neutrophil depletion with vinblastine has failed to show any bene-
1 Adams HP, Biller J. Haemorrhagic intracranial vascular disease. In: Joynt RF, ed. Clinical Neurology. Vol 2 (1989 disease. In: Joynt RF, ed. Clinical Neurology. Vol 2 Jenkins A, Mendelow AD, Graham DI, Nath FP, Teasdale 
GM. Experimental intracerebral haematoma: the role of blood consistuents in early ischaemia. $\mathrm{Br} \mathcal{F}$ Neurosurg 1990;4:45-52.

3 Nath FP, Jenkins A, Mendelow AD, Graham DI, Teasdale GM. Early hemodynamic changes in experimental intracerebral hemorrhage. $\mathcal{F}$ Neurosurg 1986;65:697-703.

4 Schuier FJ, Hossman K-A. Experimental brain infarcts in cats. II. Ischemic brain edema. Stroke 1980;11:593-601.

5 Crockard A, Ianotti F, Hunstock AT, Smith RD, Harris RJ, Symon L. Cerebral blood flow and edema following carotid occlusion in the gerbil. Stroke 1980;11:494-8.

6 Nehls DG, Mendelow AD, Graham DI, Teasdale GM. Experimental intracerebral hemorrhage: early removal of a spontaneous mass lesion improves late outcome. Neurosurgery 1990;27:674-82.

7 Suzuki J, Ebina T. Sequential changes in tissue surrounding ICH. In: Pia HW, Langmaid C, Zierski J, eds. Spontaneous intracerebral haematomas: advances in diagnosis and therapy. Berlin-Heidelberg: Springer Verlag, 1980:121-8.

8 Hallenbeck JM, Dutka AJ, Tanishima T, Kochanek PM, Kumaroo KK, Thompson CB, et al. Polymorphonuclear leukocyte accumulation in brain regions with low blood flow during the early postischemic period. Stroke 1986; 17:246-53.

9 Obrenovitch TP, Hallenbeck JM. Platelet accumulation in regions of low blood flow during the postischemic period. Stroke 1985;16:224-34.

10 Pozzilli C, Lenzi GL, Argentino C, Carolei A, Rasura M, Signore A, et al. Imaging of leukocytic infiltration in human cerebral infarcts. Stroke 1985;16:251-5.

11 Romson JL, Hook BG, Kunkel SL, Abrams GD, Schork MA, Lucchesi BR. Reduction of the extent of ischemic myocardial injury by neutrophil depletion in dog. Circulation 1985;67:1016-23.

12 Hernandez LA, Grisham MB, Twohig B, Arfors KE, Harlam JM, Grainger DN. Role of neutrophils in ischemia - reperfusion induced microvascular injury. $\mathrm{Am}$ f Physiol 1987;253:H699-703.

13 Corris PA, Odom NJ, Jackson G, McGregor CG. Reimplantation injury after lung transplantation in a rat model. ₹ Heart Transplant 1987;6:234-7.

14 Dutka AJ, Kochanek PM, Hallenbeck JM. Influence of granulocytopenia on canine cerebral ischemia induced by granulocytopenia on canine cerebral

15 Grogaard B, Schurer L, Gerdin B, Arfors KE. Delayed hypoperfusion after incomplete forebrain ischemia in the rat. The role of polymorphonuclear leukocytes. $₹ \mathrm{Cereb}$ Blood Flow Metab 1989;9:500-5.

16 Usha S, Vasthare VS, Heinel LA, Rosenwasser R, Rubins S, Tuma RF. Leukocyte involvement in cerebral ischemial reperfusion. Stroke 1989;20:147.

17 Lindsberg PJ, Siren AL, Feuerstein GZ, Hallenbeck JM. Post ischemic antagonism of neutrophil adherence has an acute therapeutic effect on functional recovery in the deteriorating stroke model in rabbits. $f$ Cereb Blood Flow deteriorating stroke model in rabb

18 Vanhoutte DM, Houston DS. Platelets, endothelium and vasospasm. Circulation 1985;72:728-34.

19 Kingman TA, Mendelow AD, Graham DI, Teasdale GM. Experimental intracerebral mass: description of model, intracranial pressure changes and neuropathology. $\mathscr{f}$ Neuropathol Exp Neurol 1988;47:128-37.

20 Coggel JE. Biological effects of radiation. London: Wykeham, 1971:71-5.

21 Haining J, Turner MD, Pantall RM. Measurement of local cerebral blood flow in the unanesthetized rat using a hydrogen clearance method. Circ Res 1968;23:313-24.

22 Young W. H2 clearance measurement of blood flow: a review of technique and polarographic principles. Stroke 1980;11:552-64

23 Sinar EJ, Mendelow AD, Graham DI, Teasdale GM. Experimental intracranial hemorrhage: effects of a temExperimental intracranial hemorrhage: effects of

24 Flecknell PA, Mitchell M. Midazolam and fentanyl-fluan- isone: assessment of anaesthetic effects in laboratory rodents and rabbits. Lab Anim 1984;18:143-6.

25 Skolleborg KC, Gronbech JE, Grong K, Abyholm FE Lekren J. Distribution of cardiac output versus midazolam/fentanyl/fluanisone anaesthesia in the rat. $\mathrm{Lab}$ Anim 1990;24:221-7.

26 Flecknell PA, Liles JH, Wootton R. Reversal of fentanyl fluanisone neuroleptanalgesia in the rabbit using mixed agonist/antagonist opoids. Lab Anim 1989;23:147-55.

27 Nelson SR, Mantz M-L, Maxwell JA. Use of specific gravity in measurement of cerebral oedema. $\boldsymbol{f}$ Appl Physiol in measurement

28 Shigeno T, Brock M, Shigeno S, Fritschka E, CervosNavarro J. The determiantion of brain water content: microgravimetry versus drying-weighing method. $f \mathrm{Neu}$ rosurg 1982;57:99-107.

29 Bailey NTJ. Statistical methods in biology. London: Hodder and Stoughton, 1976:100-8.

30 Spallone A, Acqui M, Pastore FS, Guidetti B. Relationship between leukocytes and ischemic complications following aneurysmal subarachnoid hemorrhage. Surg Neurol 1987;27:253-8.

31 Bauch C. Leucocytes in health and disease. In: Weatheral DJ, Ledingham JGF, Warrell DA, eds. Oxford Textbook of Medicine, 2nd ed, Oxford: Oxford University Press, 1987; chapter 19: 156-63.

32 Davies JA, Tuddenham GD. Haemostasis and thrombosis In: Weatherall DJ, Ledingham JGF, Warrell DA, eds In: Weatherall DJ, Ledingham JGF, Warrell DA, eds. Oxford textbook of medicine, 2nd ed, Oxf

33 Liebow AA, Warren S, De Coursey E. Pathology of atomic bomb casualties. Am $\mathcal{F}$ Pathol 1949;25:853-1027.

34 Violi F, Rasura M, Alessandri C, Intiso D, Germani $M$ Serni $M$, et al. Leukocyte response in patients suffering from acute stroke. Stroke 1988;19:1283-4.

35 Modha P, Mendelow AD, Proctor SJ, Fox C. Experimental intracerebral haematoma: ischaemic brain oedema in granulocytopenic rats. Med Sci Res 1988;16:1031-2.

36 Aspey BS, Jessimer C, Pereira S, Harrison MJG. Do leucocytes have a role in the cerebral no-reflow phenomenon? f Neurol Neurosurg Psychiatry 1989;52:526-8.

37 Schurer L, Prugner U, Peters J, Kempski O, Arfors KE Baethan A. Effect of antineutrophil serum (ANS) on
post-traumatic brain edema in rats. Acta Neurochir post-traumatic brain

38 Takeshima R, Kirsch JR, Koehler RC, Gomoll AW, Traystman RJ. Efects of neutrophil monoclonal antibody (MoAb60.3) on infarct volume following transient focal cerebral ischemia in cats. $\mathcal{F}$ Cereb Blood Flow Metab 1991; suppl 2:S752.

39 Barcikowska-Litwin M, Krajewski S, Dolinska E, Rafaoska $J$. Lymphocytes within the infarct area in human brain. Neuropatol Pol 1987;25:451-60.

40 Pelletieri L, Nilsson B, Carlsson CA, Nilsson U. Serum immunocomplexes in patients with SAH. Neurosurgery 1986;19:767-71.

41 Peterson JW, Nishizawa S, Hackett JD, Bun T, Teramura A Zervas T. Cyclosporine A reduces cerebral vasospasm after subarachnoid hemorrhage in dogs. Stroke 1990; 21:133-7.

42 Giulian D, Robertson C. Inhibition of mononuclear phagocytes reduces ischemic injury in the spinal cord. Ann Neurol 1990;27:33-42.

43 Chan PH, Fishman RA, Caronna J, Schmidley JW, Priotreau $G$, Lee J. Induction of brain edema following intracerebral injection of arachidonic acid. Ann Neurol 1983;13:625-32.

44 Moncada S, Vane JR. Pharmacology and endogenous roles of prostaglandin endoperoxides, thromboxane $\mathrm{A} 2$ and prostacyclin. Pharmacol Rev 1979;30:293-331.

45 Frerichs KV, Lindsberg PJ, Hallenbeck JM, Feverstein GZ Platelet activating factor and progressive brain damage following focal brain injury. $\boldsymbol{f}$ Neurosurg 1990;73: 223-33. 